\title{
Working With Generations X And Y In Generation Z Period: Management Of Different Generations In Business Life
}

\author{
Sezin Baysal Berkup \\ Gediz University, İzmir, Turkey \\ sezin.baysal@gediz.edu.tr
}

DOI:10.5901/mjss.2014.v5n19p218

\begin{abstract}
Mankind which is a social entity and whose most basic necessity is staying with other people have been in tendency of being together, acting together and uniting since the early ages of history. People living in the same period and therefore sharing the same conditions and even same experiences are influenced by each other. This situation results in the fact that individuals who are born, grown and brought up in the same or close periods have similar characteristics. It is not attractive that individuals who are shaped by the environment in which they are born and grown up, social, economic and cultural conditions, social cases and cases which interest the entire humanity have similar characteristics. Scientists moving from this point put forward the term "generation" in order to define individuals and their characteristics and carried out studies over this term. Within the scope of studies; the generation which was born between 1925-1945 was named as 'Traditionalists' silent generation and it was not subject of studies too much since it is regarded as a generation which does not have major effect. The generation which was born after World War II and therefore have the name of 'Baby Boomers' includes people born between 1946-1964 and representatives of this generation are regarded as those who are retired or about to retire today. The greatest aim of the generation which was born between 1965-1979 and named as 'X Generation' is considered as keeping pace with the changes in the world. Representatives of this generation have active role in social life and business life today. The generation which was born between 1980-2001 and named as 'Millennials' or as 'Y generation' as more commonly known are the children of globalization. For the children of this generation who have accessed the development and easiness of technology, technology is one of the cornerstones of life. Y generation which has an important place especially in business life has been subject for various studies today. The last generation which was born between 2000-2020 is the technology generation. Although this generation which regards technology as something indispensable has not got into business life yet, enterprises would have to make preparation for this generation within 10 years. Enterprises which are globalized and brought competition at international level today have to employ these individuals in one place who are belong to different generations therefore have different characteristics and structures. Employing rapidly changing generations of rapidly changing world in one place, keeping their motivation high and obtain efficiency from them is possible by knowing generations, learning characteristics of them and acting according to these characteristics. In this study, first of all the term generation will be mentioned, generations and their characteristics will be explained, then characteristics of different generations and formation of management process of enterprises will be discussed.
\end{abstract}

Keywords: Generations, Baby Boomers, X Gen, Y Gen, Z Gen, Generational Different, Business Management, Generational Management

\section{Introduction}

The existence of technology has caused rapid and radical changes in the 21 st century while the development and rapid changes of technology have been interacting mutually. These changes have formed the basis of new technologies. These changes experienced have brought about the people, who were born in different periods of time, to have different personalities, viewpoints and values. The changes occurred in economy, culture and politics influence the perception, expectation and viewpoints of the individuals deeply. As a result of these interactions, the borders of period of generations are marked off and their characteristics are determined. Alexis de Tocqueville, a French political thinker and historian, stated in his article called Democracy in America he wrote in 1945 that the United States of America underwent a perpetual change. He referred to the generational turnover as one of the main sources of this change while he was mentioning about aforementioned change. Each young generation, who replaces the old generation, comes along with its own characteristic feature and value judgment (Bennett \& Rademacher, 1997). Their different general point of view may change the social and political landscape. The generations, who travel together in the course of time being affected from the same events, have been examined throughout the history in order to understand the psychology of the individuals and keep their 
behaviour under control. The main reasons why so many researches carried out on the generations today are that the drastic influences of the changes experienced on the individuals can be observed more clearly and "the four generations that have four different characteristics work together" for the first time in the history as the specific period for each generation has been shortened due to the changes underwent. Understanding the generation phenomenon and its chronological difference as well as the traits of the members of generations is of importance as these four different generations that have different characteristics which are separated from one another sharply coexist.

\section{Generation Concept and Chronological Classification}

The generation term examined by the various sciences as a multidisciplinary concept is basically defined as "a series of birthdays of a group of people" (Jopling, 2004). A different definition for the generation is "the generational cohorts or groups, who belong to the same age group, experience or will experience accordingly the similar life experience in the years they may shape their lives" (Hung \& Gu \& Yim, 2008). Based on the different definitions the generation term may be defined as the groups of people who were born, grew and maintained their life in a certain period of time, and are supposed to have common characteristics and viewpoints as they are affected from the events occurred during the aforementioned period. As it may be understood from this definition, the significant point related to the generation concept is by which incidents the members of the group in question have been affected in a specific period of history and what the impressions the said incidents have left on them. The generational classes, which are defined by the experts referring to so many historical events and different impacts, differ from one another. Some experts cannot come to terms regarding the chronological classification of the generations while some of others disagree about the total number of the generations. The classification to be used in this study will be the one to be particularly based on the opinions of the experts and evaluation of the historical events though it is likely to observe a lot of different classifications when the international and national literature is reviewed.

\begin{tabular}{||l|l||}
\hline \hline Generation Name & Chronological Generation Classification \\
\hline \hline Traditionalists & $1900-1945$ \\
\hline \hline Baby Boomers & $1946-1964$ \\
\hline \hline Generation X & $1965-1979$ \\
\hline \hline Generation Y & $1980-1994$ \\
\hline \hline Generation Z & $1995-\ldots .$. \\
\hline \hline
\end{tabular}

Table 1. Chronological Generation Classification Used in This Study

\section{Generations}

\section{Traditionalists}

This generation, who are called in various sources as Silent Generation, Matures, Veterans, Seniors or Radio Babies, is composed of those who were born between 1900 and 1945. Some of the socio-cultural, politic and economic events that played a great role in shaping the personality of this generation and established the characteristic features of its members are World War I and II, Great Depression in 1929, Attack on Pearl Harbor, Atomic Bombings of Hiroshima, McCarthyism and Korean War. The wars and economic hardships are two main events the Traditionalists suffered from as they lived a considerable part of their lives under their shadows. So most of their traits are affected by these sufferings. This is why the thrifty Traditionalists, who like to save and lead a modest life without spending much, want permanency in their jobs because the financial security is of crucial importance for these people. The Traditionalists prefer having confidence in the Authority in order to protect themselves from uncertain events. They are in demand in business life thanks to their authority-lover attitude. As the individuals who experienced the war years and the Great Depression, the members of this generation whose main approach in business is 'work hard', 'work to live' and 'work comes before pleasure' tend to work much. The commitment of this generation, who may be affected by the uncertainties, to their job and business is too high as securing their financial future is of great importance. The Traditionalists, who think that securing a lifetime employment in a corporation or hierarchy (Weingarten, 2009), are supposed to be the ideal employees as they are able to manage 
themselves. Because of the influence of the Army, they like hierarchy effective approaches originating from top to bottom and take orders. Likewise their leadership style is run through a chain of command and includes in giving orders (Johnson Controls, 2010. According to these people who like discipline the fundamental tenets of business life is to respect the boss and obey the orders (Crampton \& Hodge, 2009). The factors to motivate a Traditionalists most is to do a good job, to be known as a person who does his job well, the rules and respect these rules. For the members of this generation who associate the seniority directly with the age, the older employee is the most senior and knows what the best is. As they respect for the government and authority, the ultimate thing one may think is to rock the boat, try to demolish the rules and disregard the authorities (Harrison 2007), which the Traditionalists conflict most with the other generations they team up with because they expect the other employees to work, obey the rules and orders, respect for hierarchy and authority as much as they do. There is a T balance between the family and work life of the Traditionalists who like to work hard (United Nations Joint Staff Pension Fund, 2010). Today the 95\% per cent of the Traditionalists (Crowe \& D'angelo, 2011), the youngest one aged 69 , are retired. Those who haven't retired yet work as the senior executives and advisors. Their rate is supposed to be 5 per cent. They form the $5,9 \%$ of the world population.

Their total population is 425.765 .41 (208.041.242 of them is male while 217.724 .170 of them are female) (https://www.census.gov/population /international/data/idb/worldpop.php Date Accessed: 13.06.2014. The traditionalists will have retired from the business life completely in the near future.

\section{Baby Boomers}

This gigantic generation, who is supposed to be born between 1946 and 1964, consists of about 1 billion babies who were born soon after the World War II. It is accepted to be the largest generation among the generations classified. Some of the socio-cultural, politic and economic events caused the members of Baby Boomers Generation, who is also defined as the generation that shaped the society as their numbers are high, to have different traits from those of other generations, are World War II, Cold War, Movements for Civil Rights, Sexual Revolution, Assassination of JFK, First Spacewalk, Vietnam War*, Assassination of RFK, Assassination of MLK Jr., First Moonwalk, Watergate Scandal, 1973 Oil Crisis and Space Race. The incidents such as the Watergate Scandal caused the members of this generation to be sceptical about the authority though they grew up to have a respect for it as the children of the traditionalists, who also had had respected it. This generation got so much attention from their families as their parents founded the child-centred families after they suffered from some hardships. The members of this generation, also called as "me generation", are individualist and selfish. The members of this generation had to be always individualist and competitive as about one billion babies were born in the same period. Thus they adopted the diligence as their principal. The Baby Boomers, a crowded generation, intend to on their mettle. The basic rule regarding life for them is 'live to work'. Their slogan is 'Thank God it's Monday'. In accordance with their characteristics, the members of Baby Boomers Generation believe in the importance of the team work in order to achieve their personal goals though they are competitive in business life. For the idealist members of the Baby Boomers Generation always aiming to be more successful than expected, a perfected career and work to ensure this career are highly important. "This generation who sees the diligence and sacrifice as carrying-the can to be successful started the workaholic movement" (Zemke \& Raines \& Filipczak, 2002). They attribute their careers and positions to power and authority. According to them commitment to job and achievement may be measured by the working hours. The members of the Baby Boomers Generation who act with the "Word hard and get to the top" slogan are loyal to their corporations. They believe in that working for a single corporation may bring success and this would be a proper action. The members of this generation need to have personal satisfaction so that they may have sense of belonging and maintain their personal achievements in line with those of the corporation (Timmermann, 2007) because these people expect a feedback and the messages such as "you are esteemed" and "you are needed" in return for the job they do. The factors motivating the employees of the Baby Boomers Generation are to be appreciated (Olson, 2011), awarded with money and bonuses, to gain prestige and status symbols such as title and parking spot. The internal factors motivating them are personal satisfaction, self-definition through personal achievement and perpetual self-improvement (Buahene \& Kovary, 2003). The members of this generation, who form the biggest workforce, have a difficulty in balancing between the business and family

\footnotetext{
*What separated the Traditionalists and the Baby Boomers and had considerable impacts on the latter was the Vietnam War though the members of the Baby Boomers were affected by all these aforementioned events. The main reason of this is that the Baby Boomers missed the World War II because then they were at their early age. On the other hand, the Traditionalists could not catch the Vietnam War.
} 
life as they are workaholic. In this period in which the women have involved in business life, the existence of workaholic parents may explain the cause of high divorce rate. Briefly job and working are an exciting adventure for the members of this generation whose business character is defined as 'loyal workaholic'. What they want most in their business life is constantly enhancing career, reaching a brilliant achievement in one job, improving themselves, pursuing to grow and develop, teamwork, title, status and money. Today the youngest member of this generation is 50 while the oldest one is 68. Currently most of them have retired or will be retired. Their population is 1.098 .305 .009 (570.063.962 male and 528.241.047 female) making up the 15,3 per cent of the total population (https://www.census.gov/population/international/data/idb/worldpop.php Date Accessed: 13.06.2014).

\section{Generation X}

The members of the Generation X, who are the children of the Baby Boomers generation who left their mark in history thanks to their large population, big egos and workaholic trait, were assumedly born between 1965 and 1979. The members of the Generation X whose youngest member is 35 while the oldest one is 49 have some traits of the Baby Boomers. As the numbers of the women of the Baby Boomers Generation that participated in business life reached a record level the members of the Generation X, who are the children of a workaholic generation, are called 'Latchkey Child**', which meant 'child whose parents work'. The Generation X, who stay between two bright generations, is considered as a transitional generation between the old generations remaining loyal to tradition and new generations of technology. The events that caused to shape their characters leaving their marks on them are Watergate Scandal, Vietnam War, Personal Computers, Death of Elvis Presley, Three Mile Island Accident, Iran Hostage Crisis, Assassination of John Lennon, First AIDS Cases, Space Shuttle Challenger Disaster, Fall of Berlin Wall, Gulf War and a rapidly advancing technology that could enable broadcasting of this war live on TV. Unlike their parents the $\mathrm{X}$ generation was less competitive but luckier as their population is less. They are the first generation to be able to think globally thanks to the impacts of the events occurred worldwide. Compared with the previous generations, they are more self-reliant and skilled as they grew up with less parental attention. They tend to orientate themselves as a generation of transitional period. The Xs, who were born into a World that had just started to change perpetually, prefer questioning authority unlike their parents. The Generation X, who learnt to tolerate the diversities because of the changing world and gained more creativity as they grew up in more restricted environment than the generations after them, are composed of the people who are able to analyze the situations they face, find easily what they seek for and are creative. The effects of global events of the era in which the Generation X lived and family structures are observed on their business life. The members of the Generation $X$ are mostly the children of the divorced and workaholic parents. They attach importance to the balance between work and family. The 'live to work' motto of the Baby Boomers changed as the 'work to live' for Generation X. The Xs could get responsibilities at their early ages as they lived alone. Their self-reliance is high. The most important point in their business life is to improve their career. They don't want to keep on working in a corporation where they suppose they cannot improve their career. The one of the greatest advantages of the Generation $X$ in their business life is that they open to change. The employees of the Generation $X$, who consider the change something one may be accustomed to, even besides something needed, and expect the same attitude from the company, may easily change their jobs in case it cannot satisfy their expectation. The Generation X cares the personal development. They dislike a boring and stressful workplace though they suppose it as a place to develop and learn (Miller \& Washington, 2011). For their temperament, they want an enjoyable and free working environment. Therefore they prefer working for comfortable agencies or setting up their own business. They have expectations such as flexible working hours, pleasant working environment or skill-based promotion (Berk, 2013) if they work for an institutional company. The Xs taking a different approach to the problems and pleasing to produce the alternative ideas are willing to create the difference within the company through their result-oriented attitude. Unlike their parents who associate the achievement with long working hours the members of the $\mathrm{X}$ generation, who prefer working wisely, want to spare time for themselves. The Xs were influenced considerably from the globalization, whose impacts had been begun to be felt in the 1980s, which meant the termination of the geographical borders. They were the first generation to have a global viewpoint as every place was considered to be accessible. As for their temperament they open to change and lean towards different structures. They like diversities at the companies they work for and can think globally (Reeves \& Oh, 2008). Thus it makes the Xs be first generation to focus on working abroad or prefer working for the global companies. The members of the Generation $X$ could not earn as much money as their parents could do because of the stagnant markets. The lack of money causes loss of

\footnotetext{
" The term Latchkey Child is originated from the child bearing the key of the house. As not only the fathers of the Generation X worked but also their mothers there weren't any parents to meet the child at home. So the key was strung around the child's neck and they were accordingly called as the Latchkey Child.
} 
motivation though the existence of it is not a motivational factor (Karp \& Fuller \& Sirias, 2002). One of the best motivational tools for the Generation X, who like the freedom, may be to explain a job with its details and expectations and leave him alone in doing it. Their motivation is usually high. In order to motivate them it is needed to provide feedback, provide their security and career improvement and offer the option the 'forget the rules and do it yourself' freedom at work. Unlike their grandfathers they are not the generation of writing. Therefore they do not like letters and written communication but prefer e-mail. They also like utilizing mobile phone at their work and social life. The members of the Generation X, who were born into a world where the technology just had started to develop, are luckier than the generations before them but have less knowledge than the generations after them, had to understand and use the technology. In their working life they often get help from technology, use mobile phone and laptop, check their e-mails, use Internet for various researches as well as benefit from the amenities of the technology that change every day. The members of the $\mathrm{X}$ generation are aged between 35 and 49. Their worldwide population is $1.422 .810 .583,718.599 .620$ of which are male while 704.210 .963 of which are female. The population rate of the Generation $X$ to the world population is $19,8 \%$ (https://www.census.gov/population/international/data/idb/worldpop.php (Date Accessed: 13.06.2014).

\section{Generation $Y$}

The Generation $Y$ was born between 1980 and 1984. The youngest member is 20 years old while the oldest one is 34 . The Ys are the first technologic and global generation of the world. The most distinctive trait of the Generation $Y$, which is also called as Gen Y, Millennials, Generation Next, Digital Generation, Nexters, Echo Boomers, Trophy Kids, Generation www, Net Generation, Gen N (Jain \& Pant, 2012), is that they look for an answer to the question "Why" when they confront a situation. So it is also called as Why Generation. ${ }^{* * *}$ The Generation $Y$ is three times bigger than the Generation X (Schrode \& Warren, 2003), who are their elder brothers and sisters. They were born into an over-planned world where everybody is occupied in doing something. This highly-educated generation experienced a transition from tradition to new era and defined themselves 'free souls'. Their most distinctive trait, which differs from other generations, is that they live together with the technology. Therefore it is remembered as the 'most technological generation'. Another event to have considerably influenced the $Y s$ that was affected by the globalization as a first global generation is the rapid advancement of the information and communication technologies. In addition to these main dynamics the events that played a part in personality formation of Ys are likely Dissolution of the Soviet Union, Death of Princess Diana, September 11 and Similar Terrorist Attacks, Natural Disasters, Political Scandals, War in Middle East and Reducing the Racism. Their most distinctive trait is their inclination to technology. Unlike the other generations they were born into technology and follow its daily development. The Ys often use technology in order to carry out the tasks they are commissioned. The Ys are adaptable to change beginning from their early age. We may suggest that their adaptation capacity is high. They are a generation who is able to keep pace with change, even like and want it. They are aware of speed of change. They can fulfil their all sorts of work very quickly. The Ys do not like waiting and do not know to be patient. On the other hand, the members of the Generation $\mathrm{Y}$ can think more globally than the other generations can do as they were born into a globalized world. They respect other races, sexes, ethnic origins, cultural values and sexual choices. Depending on the terrorist attacks they suffered from, instabilities in politics and their distrustfulness for authority and politicians, the Ys prefer making short-run plans to long-run plans. Another trait of the Ys is that they want any job they do to be fruitful and different. As they are resolved and selfreliant they hold their motivation high. They have ability to focus on more than one job at the same time since they are accustomed to participating in more than one course or activity as the child-centred families. The parents of the Ys are the 'helicopter parents' who always are around their children, control and protect them and meet all their requests. The message given by these parents to their children is the 'run towards home when things get worse' (Fleschner 2007), which may be maintained during the adult period of the Ys having an impact on their business life. They see the education as a key to be successful in business life. They prepare themselves for business life through the trainings and courses they get, internships they attend and the part-time jobs they do during their lifetime. They consider the workplace as an opportunity to learn as they believe in the importance of the lifelong learning. This generation likes to study expecting that the knowledge would make them powerful. Thanks to the advantage of being a technological generation the employees of the Generation $Y$ do not have any difficulty in researching and may use the information they get for their job. They easily may access to information and use it to solve the common problems of the company they work for. "The Ys have an ability to compile information from different sources and use it to solve the problems filtering out the information they gather as they are

\footnotetext{
${ }_{* * *}^{*}$ The pronunciation of the letter $Y$ in English in the Generation $Y$ is same with that of word 'Why'. In order words, when the Generation $Y$ is referred it is also meant the 'Why Generation'.
} 
exposed to information bombardment since they were born" (Buckley \& Beu, 2001). The Y employees want to be led at the corporation they work for and prefer an individual work supported by coaching. The $75 \%$ of the employees want a mentor. The $80 \%$ of them expect feedback from the executives (Adigüzel \& Batur \& Ekşili, 2014). " In order to motivate the Generation $Y$, who challenge the authority, do not like the orders and hierarchy and not are impressed by the title and position, need a manager believing in and supporting them. As the children who grew up with the family support they want the older staff to be their manager - not their fellows. They need the fellow to have fun in the workplace and set up a pleasant work environment. The Generation $Y$ expecting quick promotions because of their impatient personalities may easily change the job unless they are promoted. Changing job seems to be a normal thing for this generation. The Ys are not afraid of becoming unemployed as they trust in their families who are ready to support them. The Generation $Y$, with its character open to change, do not have a difficulty in adapting to the new companies in which they are employed. They try to establish a balance between the business and family life as they care about their families that support them not only at home but during their career. Therefore they prefer working to live to living to work. So the motto of the Generation $Y$ regarding life is the 'first live. Then work'. The members of this generation who are able to do more than one job at the same time and prefer multitasking jobs - even careers - want to be known by their careers not the job they do. The employees of the Generation $Y$ attaching importance to the spiritual values in business life and demanding their opinion to be asked always want to be active in the company. "Instead of being a part of a chain that is unaware of what it is doing, they choose to be in a critical position regarding the vision of the company and involve in the innovation works to improve the company" (Schawbel, 2013). The Generation Y like to make difference but not act in a standard way. They sometimes use the social media for communication and entertainment as well as an information repository in their business. This generation enjoys the competition in business life and intends to work in a competitive environment. As for the performance assessment they demand the differences among the individuals to be taken into consideration. As the members of a generation taking a global point of view, they do not have a problem while working for the companies that have different cultures and diversities. They can adapt to the conditions of these kinds of companies more easily and quickly than the other generations can do. The members of the Generation $Y$ work to become free not for money. They aim to improve their careers together with their seniors coaching them. They lean towards teamwork within the corporation in order to gain their personal goals. The Ys, who want to work for technology-integrated companies thanks to their entrepreneurial and innovative spirits, prefer using instant messaging and e-mail. Initially they may discourage the companies because of their different personalities. But soon after they start to work, they may make a breakthrough for the companies that achieve to obtain efficiency from them. The way to keep the $Y s$ in the company is to motivate them. The Generation $Y$ is the largest generation of the world as most of the members are online to meet their needs, maintain their daily activities and even set up a business and make money on Internet (Anderson \& Kennedy, 2006). The total population of the $Y$ generation is 1.718.260.527, 877.301.291 male and 840.959.236 female. The population rate of this generation, which is the largest generation band, to the world population is 23,9 per cent. (https://www.census.gov/population linternational/data/idb/worldpop.php Date Accessed: 13.06.2014)

\section{Generation Z}

The Generation Z, consisting of the people born since 1995, are also called as Children of Internet, Digital Generation, Digital Natives ${ }^{* * * *}$, Media Generation, .com Generation, iGen ${ }^{* * * *}$ or Instant Online (Levickaite, 2010). The most distinctive traits of the Generation Z are reliance, freedom, individualism, addiction to technology and speed. There is a great difference in terms of utilizing technology between this generation and the Generation X, who are their parents. The Zs are the children of PC, GSM and Internet. The members of the Generation Z trying to comprehend the rapidly changing world and grow up in it are the generation of the future. The evaluations carried out regarding the $Z$ generation cannot go beyond supposition as they are under age, their personalities are not maturated and it is not known what events may have an impact on them in the years to come. The Generation Z, the children of the Xs that were an important generation, is a

\footnotetext{
**** The Digital Natives term refers to that the members of the Generation Z, unlike the previous generations, were born into the technology instead of being accustomed to it. The generations before the Zs, especially the Generation Y, were not born into the technology but accustomed to using it later though they utilized it actively. They are called as the Digital Immigrants. But the Generation $Z$, who were born into the technology and considered it as a part of life, are called as the Digital Natives.

${ }_{* * * * * *}$ With the iGen naming, it is referred to the products the Apple company introduced to the market in new Millennium. The Apple launched music player iPod in 2001, the mobile phone iPhone in 2007 and the tablet computer iPad in 2010. The generation is named as iGen as these products are used intensively.
} 
complete technology generation as they were born into technology rather than being accustomed to it. They have been equipped with the technological devices since they were babies. The advancement of technology is the most distinctive trait of the $Z$ generation. Launching of the perpetually advanced products of the Apple company which are not like the others, the Facebook hitting the markets in 2004, the Twitter used by millions of users and other social media such as Instagram, Pinterest and Foursquare - especially used by the young people - have become an important part of life. It is estimated that the social media would leave impacts and cause addictions on the members of the $Z$ generation. The members of the $Z$ generation who were born into a techno-global world can get contact with any person in any location of the world in seconds and share information. The Zs that may be called as the technology addict have a command of Internet technology, play Internet-based games, socialize on Internet environment, like to be online $7 / 24$, get information from Internet and share continuously something. The members of this generation accessing to any kind of information on Internet they need are supposed to be the most connected generation ever born. The Generation Z perceive the technology as a part of usual life but not an innovation, convenience or a requirement one must be accustomed to. It is also defined as the GSM-based generation. This generation, which want anything to happen quickly and instantly because of the impact created by the advancement of technology, is impatient exactly like the Generation Y. Their attention span is short. One of the positive traits contributed to this generation by the Internet technology is that they are able to be interested in more than one subject at the same time. As their ability to be interested in more than one issue is highly advanced, they are thought to have the highest motor skill synchronization for hand, eye and ear in the history of humanity. The Zs like activities and games allowing creativity. Their most distinct traits are socializing through Internet, consuming rapidly, practicality and speed, interactivity, efficiency, dissatisfaction and being result-oriented. They suppose anything possible in the World and can do everything thanks to their equipment. Their self-reliance is high. They tend to be efficient and innovative. They are expected to live under better living standards, longer and be wealthier than the previous generations thanks to the advanced technology. The Zs still continue to study today. As compared with the previous generations they start to be educated at the earlier age and get a developed and planned education. They may benefit from the advantages of the education they get in business life. Just a few of them can work because of their age. Based on the specified traits of the Generation Z, they are expected to have characteristics such as multitasking, efficient technology utilization, individualism (not to like the teamwork), creativity, global point of view and preference of non-standard and personalized works. The aforementioned traits cannot be beyond a supposition as the economic and political processes that may be arisen when the Zs reach the working age.

\section{Differences among Generations in Business Life}

The members of generations who were born in different eras and grew up under quite different conditions may exhibit behaviours depending on their traits when they get out to work. The differences among the viewpoints of the generations regarding the business must be known and these differences must be steered as the gap among the generation is shortened and consequently sometimes 3 or 4 generations have to work together because of the changed conditions.

The Table 2 compare the traits of the $X$ and $Y$ generations, which are the most effective members of the working life, regarding the business life. In this table only these two generations are evaluated because the members of the Traditionalists and Baby Boomers have already retired or about retiring and the $Z$ generation has not yet started to work. Therefore these generations were excluded in evaluation.

Comparison of Business Values and Viewpoints of Generation $X$ and $Y$ regarding Business Life

\begin{tabular}{|l|l|l|}
\hline $\begin{array}{l}\text { Business Values and Viewpoints } \\
\text { regarding Business Life }\end{array}$ & Generation X & Generation Y \\
\hline \multirow{3}{*}{$\begin{array}{l}\text { Basic Values and Beliefs regarding } \\
\text { Job and Company }\end{array}$} & $\begin{array}{l}\text { Work to live. Work wisely rather than } \\
\text { working long hours, } \\
\text { Request for structure and guidance } \\
\text { Scepticism }\end{array}$ & $\begin{array}{l}\text { Living comes before working, } \\
\text { Working much by having fun, } \\
\text { Multitasking, } \\
\text { Entrepreneurship, } \\
\end{array}$ \\
& Tolerance for diversities \\
\hline
\end{tabular}




\begin{tabular}{|c|c|c|}
\hline $\begin{array}{l}\text { Educational Background for Success } \\
\text { in Business }\end{array}$ & A road to be able to go there & Incredibly high-priced spending \\
\hline Career Improvement & $\begin{array}{l}\text { A flexible career, } \\
\text { A proactive approach to career } \\
\text { improvement for more promotion and } \\
\text { experience within and outside } \\
\text { corporation, } \\
\text { Willing to know all options }\end{array}$ & $\begin{array}{l}\text { Parallel (Multiple) careers, } \\
\text { Entering business life with more } \\
\text { experience, } \\
\text { Asking opportunities and experience, } \\
\text { Often and quick change in career } \\
\text { goal }\end{array}$ \\
\hline Working Style & $\begin{array}{l}\text { Working until obtaining a result, } \\
\text { A mentality 'Let you have a life', } \\
\text { Adaptation of office and home to } \\
\text { flexible picture, } \\
\text { Flexible working style }\end{array}$ & $\begin{array}{l}\text { Short-term and flexible working, } \\
\text { Willingness to designate workplace } \\
\text { and time, } \\
\text { Adaptation of office and home to } \\
\text { flexible picture, } \\
\text { Changeable working style }\end{array}$ \\
\hline $\begin{array}{l}\text { Communication Style in Job } \\
\text { Environment }\end{array}$ & $\begin{array}{l}\text { Informal, direct and electronic } \\
\text { communication } \\
\text { Need for feedback, } \\
\text { Communication with customer } \\
\text { through e-mail, } \\
\text { Seeing the colleagues as friends, } \\
\text { Open communication with colleagues } \\
\text { to solve the conflicts }\end{array}$ & $\begin{array}{l}\text { Quick, informal, direct and advanced } \\
\text { technology-based communication, } \\
\text { Communication with customer } \\
\text { through e-mail, instant messaging } \\
\text { and messaging. } \\
\text { Purpose-oriented and motivation } \\
\text { providing communication, } \\
\text { Informal and social relations with } \\
\text { colleagues, } \\
\text { Discussing and challenging in case a } \\
\text { conflict arises }\end{array}$ \\
\hline $\begin{array}{l}\text { Loyalty to Corporation and Job } \\
\text { Changing }\end{array}$ & $\begin{array}{l}\text { Changing job if necessary, } \\
\text { Listening to inner feelings }\end{array}$ & Job changing is an expected event \\
\hline $\begin{array}{l}\text { Balance between Business and } \\
\text { Social Life }\end{array}$ & $\begin{array}{l}\text { A clearer balance between family and } \\
\text { work }\end{array}$ & $\begin{array}{l}\text { Not only balance between business } \\
\text { and life but also among business, } \\
\text { relations and personal improvement } \\
\text { Flexible hours. Work sharing }\end{array}$ \\
\hline Job Expectations & $\begin{array}{l}\text { Needing cause for task, } \\
\text { Needing or seeking a connection for } \\
\text { another position }\end{array}$ & $\begin{array}{l}\text { Pleasant working environment, } \\
\text { Desire to make difference }\end{array}$ \\
\hline $\begin{array}{l}\text { Education, Development } \\
\text { Consultancy }\end{array}$ & $\begin{array}{l}\text { Willingness to know what's exactly } \\
\text { demanded, } \\
\text { Flexibility in learning, } \\
\text { Informal team structure and working } \\
\text { independently with less control, } \\
\text { Leadership mentality based on talent } \\
\text { and skill }\end{array}$ & $\begin{array}{l}\text { Willingness to take risk. Ignore } \\
\text { making mistake and consider it as an } \\
\text { education, } \\
\text { Teamwork, } \\
\text { Training with fun, } \\
\text { Individual work through control and } \\
\text { guidance, }\end{array}$ \\
\hline
\end{tabular}




\begin{tabular}{|c|c|c|}
\hline & & $\begin{array}{l}\text { Leadership based on harmony and } \\
\text { unity }\end{array}$ \\
\hline Feedback related to works carried out & $\begin{array}{l}\text { It would be sufficient to describe the } \\
\text { general structure of the task thanks to } \\
\text { their self-sufficient personalities }\end{array}$ & $\begin{array}{l}\text { Teamwork, } \\
\text { Asking feedback }\end{array}$ \\
\hline $\begin{array}{l}\text { Authority Concept and Corporate } \\
\text { Structure }\end{array}$ & $\begin{array}{l}\text { Less confidence in authority } \\
\text { Not to be affected by authority, } \\
\text { Changing bureaucratic rules }\end{array}$ & $\begin{array}{l}\text { High confidence in authority, } \\
\text { Not to accept bureaucratic rules, } \\
\text { Respecting the authority that may } \\
\text { enable them to improve their talents }\end{array}$ \\
\hline Technology in Working Environment & $\begin{array}{l}\text { Technology must be utilized if it is } \\
\text { necessary to achieve, } \\
\text { Using mobile phone and laptop, } \\
\text { Utilizing Internet for researches, } \\
\text { Checking e-mails and mobile phones } \\
\text { for } 7 / 24\end{array}$ & $\begin{array}{l}\text { Willingness to work with up-to-date } \\
\text { technology, } \\
\text { Utilizing technology as a tool to fulfil a } \\
\text { better work, } \\
\text { Creating database and utilizing } \\
\text { Internet to research and set up } \\
\text { network, } \\
\text { Checking e-mails, mobile phones and } \\
\text { instant messages for } 7 / 24\end{array}$ \\
\hline Retirement & $\begin{array}{l}\text { The mentality 'I may retire earlier if I } \\
\text { save my money', } \\
\text { Desire to have different experiences } \\
\text { and careers }\end{array}$ & $\begin{array}{l}\text { It remains uncertain though it has } \\
\text { traits similar to those of Generation } Y\end{array}$ \\
\hline Motivational Tools and Rewards & $\begin{array}{l}\text { Freedom } \\
\text { Fun } \\
\text { Fair remuneration, } \\
\text { Extra earning in return for extra } \\
\text { working, } \\
\text { Enjoyable atmosphere, } \\
\text { Let them question authority and } \\
\text { experts }\end{array}$ & $\begin{array}{l}\text { Personal Satisfaction, } \\
\text { Opportunity given to take } \\
\text { responsibility of a project and be part } \\
\text { of team, } \\
\text { Need for entertainment and control } \\
\text { over environment, } \\
\text { Meaningful work, } \\
\text { Becoming a hero, } \\
\text { Working with creative people, } \\
\text { Flexible working, } \\
\text { Gaining new skills. New learning } \\
\text { opportunities }\end{array}$ \\
\hline Diversity inside Corporation & United & No race for majority \\
\hline Give me more.... in work environment & Time & Acknowledgement \\
\hline Job & The fastest way to get result & Satisfaction \\
\hline Career......... & It is a part of mine & It is an opportunity to be appreciated \\
\hline Basic Demand regarding Work & Being enterprising. & Follow a hero. \\
\hline
\end{tabular}

Table 2. Comparing Traits of Generations regarding Business Life 


\section{Proposals and Conclusions concerning Management of Generations $X$ and $Y$}

In today's techno-global world the thousands of companies from all countries compete in a giant global market. The companies, operating in an environment where all the technological conditions are similar or same, all the features are easily and rapidly imitable, the number of the conscious customers is high and many competitors exist, may build different human resources. Where all the technologies and conditions are imitable in today's business life, one of the most important elements of a company that is not imitable and adding value to it is its employees. The employees of a company are highly important people as they could sustain the company. Therefore the traits and expectations of these individuals must be known and the human resources strategy of the concerning company must be implemented in this direction. Today the most of the employees are composed of the members of the Generation $X$ and $Y$. Identifying the characteristic features and their point of view regarding business life of the aforementioned generations is a facilitative condition in order to motivate and manage them. Though the business principal of the Xs, who are the transitional generation in terms of getting used to the advancing technology and intending to balance between the work and family life because of their workaholic parents, is to work to live they have high self-confidence and tendency for teamwork.

The Xs considers the career improvement as the most important condition. They like to change and demand the change in their workplace. Satisfaction of their expectations and providing of motivation is highly significant to ensure their permanency at work as they quit the company easily if they cannot find what they expect. Today the youngest member of the Generation $\mathrm{X}$ is 35 while the oldest one is 49 . Some of the conditions ensuring their motivation inside the company are as follows:

Existence of a structure caring personal development and providing improvement opportunities,

Enjoyable and freedom-based working environment,

Proposing flexible working hours,

Proposing skill-based promotion opportunities,

Giving orders clearly and explaining expectations when a task is commissioned,

Leaving them alone and free so that they could carry out the work after the detailed information regarding to a stint is given, A perpetual feedback concerning the works they have completed,

Existence of a flexible working style so that they could balance between business and family life,

Questioning the authority when needed and giving freedom.

Aforementioned conditions enable the motivation of the Xs, set ground for fulfilling of the jobs by the employees and contribute to development of both company and employee. For the members of the Ys, who are well educated, seeking for learning opportunities, are inquisitive and innovative, the two most important issues are a career creating value and existence of a leader who may guide them in accomplishing their career. Like their elder sisters and brothers, namely the Generation X, the Ys may easily change the job unless they can find what they expect. One of the advantages of this generation is the existence of their families willing to support them when they intend to change their job. The basic questions asked by the Ys so that they feel satisfied from any job are 'Is this job satisfactory and interesting?' and 'Is it meaningful and important to work in this job?' (Kaye, 2012). They would not remain at the company and be motivated by money if the answers of these questions are not positive. Some of the conditions to be taken into account to motivate and ensure the achievement of the Ys, whose youngest member is 20 while the oldest one is 34 , are as follows:

They must be guided by an senior export so that they could improve their career,

Orientations and recommendations regarding their career by a staff whom they may consider as a leader within the company,

Ensuring the conditions such as flexible working hours so that they could concentrate on work better, easygoing in appearance and behaviour, sparing more personal time in company, determination of working hours and place by themselves and comfortable working environment,

Letting them establish an enjoyable working environment with their fellows,

Details of the task given. Description of the objectives and providing open-orientation, 
Feedback regarding the works they do is essential,

Establishment of responsibilities so that they may express themselves and prove their distinctiveness,

Performance evaluation must not be based on the criteria such as seniority or working hours. It must be evaluated according to individual differences such as achievement, creativity and innovativeness at the end of the operation.

Proposing a working environment in which they may spare time for their families who are very important for them and establish a balance between their family and business,

Opportunities to create meaningful works,

Not allow them to be passive relating to the important issues of the company. They must be allowed to participate in operation and given chance so that they could be successful in this operation.

Supporting the team work so that they improve their career and achieve their personal goals,

Allow them to work with bright and creative individuals to widen their horizon,

Turning the information sharing within company into a culture.

The Ys have a capacity to be able to create big values for the company provided that aforementioned conditions are ensured. A manager, who has worked with the Generation $Y$ and been able to ensure the achievement of the employees and the company, is the lead manager stating about the speed of the work and give information on it to the Generation $Y$ as well as focusing the results of the job they carried out. When the factors motivating the employees are considered, it is observed that ensuring a perpetual improvement of their careers and providing an easygoing working environment to them are required for both $Y s$ and $X s$. Though the expectations of these two generations may be seen and criticized by their grandparents, who are loyal to authority, and the Baby Boomers, who are their workaholic parents, as caprice or laziness, these expectations should be considered as a new requirement for the current business life which is technology-driven and global-focused. These generations are not likely to be managed by the old business strategies as they are much well educated than the previous generations, specialists in their fields, can easily access to information thanks to their high command of Internet and technology, thus creating differences. It is predicted that the companies that are able to establish business environment in accordance with the expectations of these generations and motivate them may be superpower in the future thanks to these success-oriented employees.

\section{References}

ADIGÜZEL, O. BATUR, Z. EKŞiLI, N. (2014) Generation's Changing Side And The Newly Arisen Work Style After Y-

Generation: Mobile Collars, Journal of Süleyman Demirel University Institute of Social Sciences Year: 2014/1, Number:19

ANDERSON, D. KENNEDY, L. (2006) Baby Boomer Segmentation: Eight is Enough, Consumer Insight, Fall/Winter 2006

BENNETS. E. RADEMACHER, W.E, 1997After The Boom: The Politics Of Generation X, Edited By Stephen C. Craig

And Stephen Earl Bennett, Rowman \& Littlefield Publishers, C1997 Published In USA, Bostan Way,

Lanham, Maryland 20706

BERK, R. (2013) Multigenerational Diversity In The Academic Workplace: Implictions for Practice, Journal of Higher

Education Management28(1), pp. 10-23

BUAHENE, A. KOVARY, G. (2003) The Road to Performance Success: Understanding and Managing the

Generational Divide, n-gen People Performans Inc.,

BUCKLEY, R. BEU D. NOVICEVIC M. SIGERSTAD T. (2001) Managing Generation Next: Individual and Organizational

Perspectives", Review of Business, Vol.22/1

CRAMPTON, S, HODGE, J. (2009) Generation Y: Unchartered Teritory, Journal of Business \& Economics Research,

Vol. 7, Number:4

CROWE, J. D’ANGELO, G. (2011) Working Across Generations, http://www.powershow.com/ view/32581- 
NGUZN/WORKING_ACROSS_GENERATIONS_powerpoint_ppt_presentation, (Date Accessed: 03.06.2014)

FLESCHNER, S. (2007) Counseling Across Generations:Bridging the Baby Boomer, Generations X, and Generations Y Gap, American Counselling Outfitters

HARRISON, L.(2007), Managing Today's Multigenerational Workforce

http://www.ushistory.org/us/53a.asp (Date Accessed: 03.06.2014)

https://www.census.gov/population/international/data/idb/worldpop.php (Date Accessed: 13.06.2014)

HUNG K., F. Gu, C. Yim,(2008) A Social Instutional Approach to Identifying Generation Cohorts in China with a Comparison of American Consumers, Journal of International Business Studies, 38, pp.836-853

JAIN V., PANT S. (2012) Navigating Generation Y For Effective Mobile Marketing In India: A Conceptual Framework, Mobile Marketing Association IJMM, Vol.7, No.3, Winter 2012

Johnson Controls, Global WorkPlace Innovation, Generation Y and the Workplace Annual Report, 2010

JOPLING, J. (2004) Understanding Generations, West Virginia University, Extension Service

KARP, H., FULLER C. SIRIAS, D.anilo (2002) Bridging The Boomer Xer Gap : Creating Authentic Teams For High Performance At Work. Palo Alto, CA: Davies-Black Pub

KAYE, B. (2012) Four Generations: Develop and Engage Them at Work, Leadership Excellence

LEVICKAITE, R. (2010) Generations X Y Z: How Social Networks Form The Concept Of The World Without Borders The Case Of Lithuania, LIMES

MILLER, R. WASHINGTON, K. (2011) Consumer Behavior, Richard K Miller \& Associates

OLSON, P. (2011) The Power of 4 he Four Generations: Who They Are, Adayana, 2011

REEVES T. C., OH E. (2008) Generational Differences, Generational Differences, in Handbook of Research on

Educational Communication and Technology, J.M.Spector, M.D.Merrill, J.V.Merrienboer, M.P.Driscoll, (Eds.). 3th ed. Athens, Georgia., p.296-297

SCHAWBEL, D., (2013) Millenials vs. Baby Boomers: Who Would You Rather Hire? http://business.time.com/millenialsvs-baby-boomers-who-would-you-rather-hire (Date Accessed: 18.06.2014)

SCHRODER, S. WARREN, Z. (2005) Get to Know Gen X - and its Segments, Multichannel News, 26(12)

TIMMERMANN, S. (2007) What a Difference a Genration Makes: How Our Life Experences Shape Our Viewpoints and

Behaviors, Journal of Financial Service Professionals

United Nations Joint Staff Pension Fund (2010) Traditionalists, Baby Boomers, Generation X, Generation Y and

(Generation Z) Working Together, http://www.un.org/staffdevelopment/pdf/Designing\%20

Weingarten, R. M. (2009) Four Generations, One Workplace: A Gen X-Y Staff Nurse's View Of Team Building İn The

Emergency Department. Journal Of Emergency Nursing. 35 (1), pp. 27-30.

ZEMKE R., RAINES C. FILIPCZAK B. (2002)Generations At Work: Managing the Clash of Veterans, Boomers, Xers and Nxters in Your Worklace, AMA Publications, New York 